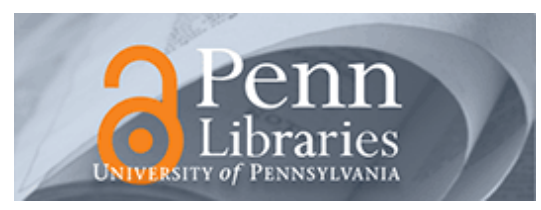

Manuscript Studies

Volume 1

Issue 1 Spring 2017

Article 3

2017

\title{
The Materiality of South Asian Manuscripts from the University of Pennsylvania MS Coll. 390 and the Rāmamālā Library in Bangladesh
}

Benjamin J. Fleming

University of Pennsylvania, fleming_b4@hotmail.com

Follow this and additional works at: https://repository.upenn.edu/mss_sims

Part of the Library and Information Science Commons, Medieval Studies Commons, Reading and Language Commons, and the South and Southeast Asian Languages and Societies Commons

\section{Recommended Citation}

Fleming, Benjamin J. (2017) "The Materiality of South Asian Manuscripts from the University of Pennsylvania MS Coll. 390 and the Rāmamālā Library in Bangladesh," Manuscript Studies: Vol. 1 : Iss. 1 , Article 3.

Available at: https://repository.upenn.edu/mss_sims/vol1/iss1/3

This paper is posted at ScholarlyCommons. https://repository.upenn.edu/mss_sims/vol1/iss1/3

For more information, please contact repository@pobox.upenn.edu. 


\title{
The Materiality of South Asian Manuscripts from the University of Pennsylvania MS Coll. 390 and the Rāmamālā Library in Bangladesh
}

\author{
Abstract \\ The codex has become ubiquitous in the modern world as a common way of presenting the materiality of \\ texts. Much of the scholarship on the History of the Book has taken this endpoint for granted even when \\ discussing pre-modern writing and manuscript cultures. In this essay, I would like to open the discussion \\ to other possibilities. I will draw on my research on medieval South Asian religions and from my hands-on \\ work with manuscripts in two collections: the Rāmamālā Library in Bangladesh and the Indic collection at \\ the University of Pennsylvania. Drawing examples from these two collections as well as noting broader \\ patterns within them, this essay reflects on what South Asian manuscript traditions can contribute to our \\ understanding of the materiality of texts. First, I consider how different articulations of orality, memory, \\ ritual, and aesthetics in Hinduism, Buddhism, and Jainism helped to shape the development and \\ formation of manuscript traditions in South Asia with dynamics that might differ from medieval \\ manuscript traditions shaped by Christianity in the West. Then, I turn to specific insights into the \\ materiality of South Asian manuscripts in relation to the task of cataloguing, preserving, and digitizing \\ materials in the Rāmamālā library.

\section{Keywords} \\ Endangered archives, bibliography, digital surrogates, material manuscript literacy, digitization, \\ manuscript cataloging, information science, Bangladesh, Bengali language, Sanskrit studies, Sanskrit \\ manuscripts, Bengali manuscripts, British Library, Hindu studies, Hindu manuscripts, Bengali scripts, \\ South Asian scripts, Colonial period, Comilla, Ramamala Library
}


Fleming: The Materiality of South Asian Manuscripts from the University of

\title{
MANUSCRIPT STUDIES
}

A Journal of the Schoenberg Institute for Manuscript Studies

VOLUME 1, NUMBER 1

(Spring 2016)

\begin{abstract}
Manuscript Studies (ISSN 2381-5329) is published semiannually
by the University of Pennsylvania Press
\end{abstract}

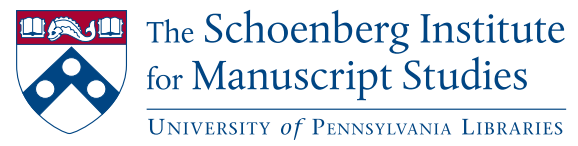




\title{
Manuscript Studies, Vol. 1 [2017], Iss. 1, Art. 3
}

\section{MANUSCRIPT STUDIES}

\author{
VOLUME 1, N U MBER 1
}

(Spring 2016)

ISSN 2381-5329

Copyright (C) 2016 University of Pennsylvania Libraries and University of Pennsylvania Press. All rights reserved.

Published by the University of Pennsylvania Press, 3905 Spruce Street, Philadelphia, PA 19104.

Printed in the U.S.A. on acid-free paper.

Manuscript Studies brings together scholarship from around the world and across disciplines related to the study of premodern manuscript books and documents, with a special emphasis on the role of digital technologies in advancing manuscript research. Articles for submission should be prepared according to the Chicago Manual of Style, $16^{\text {th }}$ edition, and follow the style guidelines found at http://mss.pennpress.org.

None of the contents of this journal may be reproduced without prior written consent of the University of Pennsylvania Press. Authorization to photocopy is granted by the University of Pennsylvania Press for libraries or other users registered with Copyright Clearance Center (CCC) Transaction Reporting Service, provided that all required fees are verified with CCC and paid directly to CCC, 222 Rosewood Drive, Danvers, MA 01923. This consent does not extend to other kinds of copying for general distribution, for advertising or promotional purposes, for creating new collective works, for database retrieval, or for resale.

\section{SUBSCRIPTION INFORMATION:}

Single issues: $\$ 30$

Print and online subscriptions: Individuals: $\$ 40$; Institutions: \$90; Full-time Students: $\$ 30$ International subscribers, please add $\$ 18$ per year for shipping.

Online-only subscriptions: Individuals: $\$ 32$; Institutions: $\$ 78$

Please direct all subscription orders, inquiries, requests for single issues, address changes, and other business communications to Penn Press Journals, 3905 Spruce Street, Philadelphia, PA 19104. Phone: 215-573-1295. Fax: 215-746-3636. Email: journals@pobox.upenn.edu. Prepayment is required. Orders may be charged to MasterCard, Visa, and American Express credit cards. Checks and money orders should be made payable to "University of Pennsylvania Press" and sent to the address printed directly above.

One-year subscriptions are valid January 1 through December 31. Subscriptions received after October 31 in any year become effective the following January 1 . Subscribers joining midyear receive immediately copies of all issues of Manuscript Studies already in print for that year.

Postmaster: send address changes to Penn Press Journals, 3905 Spruce Street, Philadelphia, PA 19104.

Visit Manuscript Studies on the web at mss.pennpress.org. 


\title{
The Materiality of South Asian Manuscripts from the University of Pennsylvania MS Coll. 390 and the Rāmamālā Library in Bangladesh
}

\author{
BenJAMIN J. FLEMING \\ University of Pennsylvania
}

He CODEX HAS BECOME wholly ubiquitous in the modern world
as a common way of compiling, presenting, and conceiving of
the materiality of texts. Not surprisingly, much of the scholarship on the history of the book has taken this endpoint largely for granted even when discussing premodern writing practices and manuscript cultures. In this essay, I would like to open the discussion up to other possibilities for understanding the history of material texts by looking to non-Western contexts with different histories and trajectories. The much-discussed phenomenon of the Christian popularization of the codex as the prehistory of the modern print "book" has a very particular history and trajectory, beginning from a particular region, time, and place. In what follows, I would like to look to other histories and trajectories, charting some of the possibilities that South Asian cultures, in particular, have presented us when merging the notion of "text" with particular material forms resonating with specific local, regional, and religious contexts.

To do so, I will draw on my research on medieval South Asian religions but also from my extensive hands-on work on manuscripts in two collections: (1) the Rāmamālā Library in Comilla, Bangladesh, which houses about nine 
Manuscript Studies, Vol. 1 [2017], Iss. 1, Art. 3

Fleming, The Materiality of South Asian Manuscripts

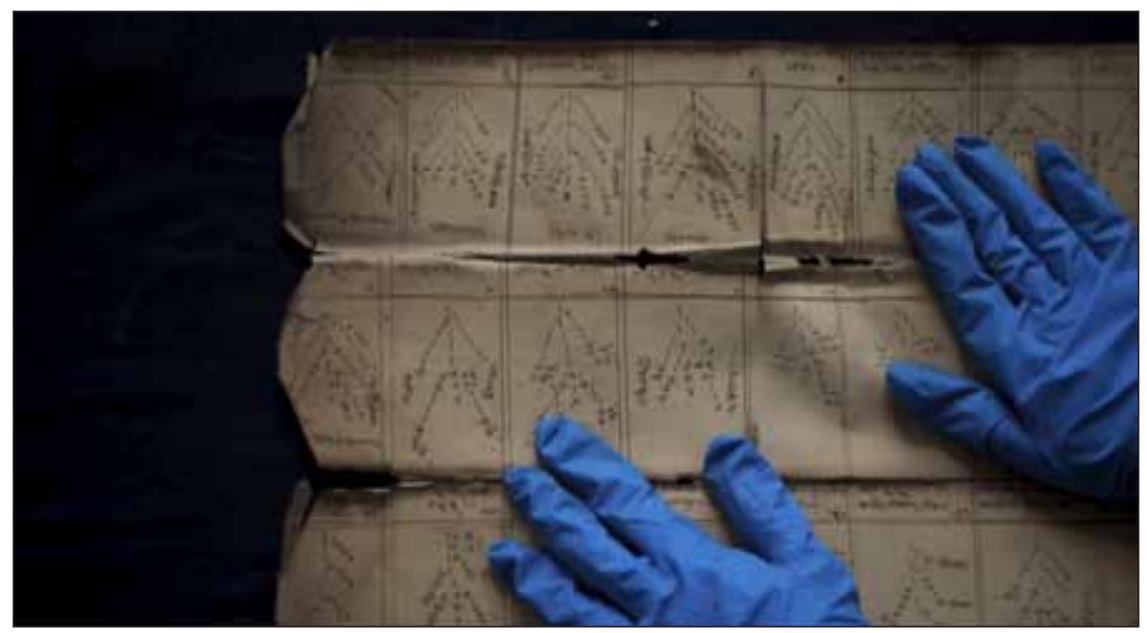

FIGURE 1. Working with a manuscript from the Rāmamālā Library in Comilla, Bangladesh. Example shows a 19th c. Pañjikā (astrological almanac). Photo by Benjamin Fleming.

thousand manuscripts that I worked to catalogue for a pilot project funded by the British Library Endangered Archive Programme, with further training and support from the Schoenberg Institute for Manuscript Studies (fig. 1), ${ }^{1}$ and (2) my NEH-funded and related work with the Indic collection at the University of Pennsylvania (MS Coll. 390), which houses about three thousand items and represents the largest collection of South Asian manuscripts in North America. ${ }^{2}$ The manuscripts in the Rāmamālā Library are from Bangladesh and mainly in Sanskrit and Bangla. At Penn, the designation "Indic" is used in a very broad sense to include regions of South Asia, such as India,

1 “The Rāmamālā Library Project," British Library Endangered Archive Programme, Pilot Project, EAP683 (principal investigator, Benjamin Fleming), 2013-2014.

2 “Providing Global Access to Penn's Indic Manuscripts, circa 1527-1930," National Endowment for the Humanities PW-51547-14 (project director, David McKnight), 20142017. A preliminary listing can be found in H. I. Poleman, A Census of Indic Manuscripts in the United States and Canada (New Haven: American Oriental Society, 1938). Currently, entries and images can be found online through Penn in Hand (http://dla.library. upenn.edu/dla/medren/); as of March 2016, selecting "Indic Manuscripts" yields over 2,200 entries. 
Pakistan, Bangladesh, Nepal, and Sri Lanka, but also regions of Southeast Asia, such as Burma, Thailand, Cambodia, Laos, and Java. ${ }^{3}$

Drawing examples from these two collections as well as noting broader patterns within them, this essay reflects on what South Asian manuscript traditions can contribute to our understanding of the materiality of texts more broadly. First, I consider how different articulations of orality, memory, ritual, and aesthetics in Hinduism, Buddhism, and Jainism helped to shape the development and formation of manuscript traditions in South Asia with dynamics that might differ from medieval manuscript traditions shaped by Christianity in the West. Then, I turn to specific insights into the materiality of South Asian manuscripts in relation to the task of cataloguing, preserving, and digitizing materials in the Rāmamālā Library.

\section{Orality, Memory, Materiality, and South Asian Manuscripts}

South Asian manuscripts are usually comprised of very long, thin, and loose folios, originally derived from trees, primarily dried palm or banana tree leaves. Later, the shape of the palm leaf manuscript was imitated with regionally-made papers from wood pulp and cotton blends, beginning with the introduction of paper into South Asia by Islamic cultures around the tenth century. Each region of South Asia developed its own variations on

3 This scope is not merely arbitrary but reflects the interconnections in this area. When asking "What, then, really defines an 'Indian manuscript'?" in his recent survey article on the topic, for instance, Dominik Wujastyk observes: "For most specialists, this expression conjures up the idea of a hand-written document inscribed on paper or palm leaf, in Devanāgarī or one of the other alphabets of South or Central Asia, and typically in the Sanskrit, Tamil, or Persian language. But one has to bear in mind that the boundaries of definition are fluid, and that a manuscript from China, written on birch-bark in the Kharoșthī script of Gandhāra and the Middle-Iranian language called Khotanese, may also be considered, in many respects, an Indian manuscript"; "Indian Manuscripts," in Manuscript Cultures: Mapping the Field, ed. Jörg Quenzer, Dmitry Bondarev, and JanUlrich Sobisch (Berlin: de Gruyter, 2014), 159-81 at 159. 
Manuscript Studies, Vol. 1 [2017], Iss. 1, Art. 3

this form, suited to available materials and regional scripts. Local expressions evolved through interaction and symbiosis.

One of the most intriguing dynamics across different regional and religious traditions in South Asia is the persistent continuity in the physical form of manuscripts. ${ }^{4}$ Writing in the early eleventh century, the Muslim author Muhammad ibn Ahmad Bīrūnī describes the material texts of India as follows:

The Hindus have in the south of their country a slender tree like the date and cocoa-nut palms, bearing edible fruits and leaves of the length of a yard, and as broad as three fingers put beside the other. They call these leaves tari (tala or $\operatorname{tar}=$ Borassus flabelliformis) and write on them. They bind a book on these leaves together on a cord on which they are arranged, the cord going through all the leaves by a hole in the middle of each. In central and northern India people use the bark of the tuz tree, ${ }^{5}$ one kind of which is used as a cover for bows. It is called bhurja. They take a piece one yard long and as broad as the outstretched fingers of the hand, or somewhat less, and prepare it in various ways. They oil and polish it to make it hard and smooth, and then they write on it. The proper order of the single leaves is marked by numbers. The whole book is wrapped up in a piece of cloth and fastened between two tablets of the same size. Such a book is called puthi (cf. pusta, pustaka). ${ }^{6}$

4 Together with its famous Sanskrit holdings, for instance, Penn holds a wealth of Buddhist manuscripts and printed works from South and Southeast Asia and from Tibet. There are also some beautifully painted manuscripts from Thailand, as well as several lacquered Pali texts from Burma (present-day Myanmar) and many works from Sri Lanka. All of the Buddhist material is found on long palm-leaf manuscripts, with the exception of works from Thailand, which are on locally made paper in an "accordion" style (linked folios), and those from Tibet, which are printed works on paper.

5 The writing material from the tuz tree (scientific name: betula utilis) is known in Sanskrit as bhürja-patra, derived from birch trees growing in the Himalayas; D.C. Sircar, Indian Epigraphy (New Delhi: Motilal Banarsidass, 1965), 64.

6 Edward Sachau, trans. Alberuni's India (repr. ed.; New Delhi: Munshiram Manoharlal, 2005 [1910]), 171. 
This description applies surprisingly well even to the much later manuscripts that make up the bulk of surviving material texts from this region. Only late examples of South Asian manuscripts bear any influence from the Western-style book. Even though the codex would have been long known in the Indian subcontinent, it was not widely adapted and adopted until around the eighteenth century. Likewise, despite the longstanding and widespread availability of printing technologies across Asia, it was only in the nineteenth century that they were widely adopted in India and displaced the role of the traditional manuscript scribe.

The physical form of manuscripts, however, is only part of the material experience of "text." South Asia, after all, is well known for the prominence of memorization and oral recitation in the formation, transmission, and preservation of intellectual traditions. The written word had initially been viewed with a certain amount of suspicion, and long after the spread of writing and literacy, textuality generally remained subordinate to the mastery of sound and words of a work in embodied memory and oral performance. ${ }^{8}$ This dynamic is most famous from the Vedas. ${ }^{9}$ Traditional Brahmanical modes of Vedic transmission rely entirely on mnemonic devices. It is only after the tenth century CE that we begin to see evidence of specific Vedic "texts." Even afterward, oral recitation and lineages of memory retain more prestige; "knowledge of the Veda," as Ludo Rocher notes, "is deemed useless if acquired from books."

Even the development of writing in the Indian subcontinent is currently debated among scholars. ${ }^{11}$ One finds early evidence for what appear

7 Graham Shaw, "South Asia," in Companion to the History of the Book, ed. Simon Eliot and Jonathan Rose (Malden, MA: Blackwell, 2007), 126-37.

8 For a variety of ancient as well as modern examples, see Ludo Rocher, "Orality and Textuality in the Indian Context," Sino-Platonic Papers 49 (1994): 1-28; D. Venkat Rao, Cultures of Memory in South Asia: Orality, Literacy and the Problem of Inberitance (New Delhi: Springer India, 2014), 59-88.

9 For an accessible introduction to this material, see Michael Witzel, "Vedas and Upanișads," in The Blackwell Companion to Hinduism, ed. Gavin Flood (Malden, MA: Wiley, 2008), 68-101.

10 Rocher, "Orality and Textuality," 8.

11 For a concise summary see Richard Salomon, Indian Epigraphy: A Guide to the Study of Inscriptions in Sanskrit, Prakrit, and the Other Indo-Aryan Languages (Oxford: Oxford Unviersity Press, 1998), 10-14. 
to be non-linguistic signs used in trade but not writing per se. ${ }^{12}$ The oldest unequivocal examples of writing to survive in South Asia date from around the fourth century BCE-that is, the inscriptions in Brahmi script on stone pillar monuments commissioned by the Mauryan king Aśoka. Other early examples of evidence for writing include the birchbark manuscript scrolls found in the Afghanistan region, which are related to Gandhāran culture and its distinctive forms of Buddhism, beginning around the first century CE. ${ }^{13}$ This early interest in writing within a Buddhist context may have something to do with that religion's outsider status — at least from the perspective of Brahmanical orthodoxy; ${ }^{14}$ from a ritual perspective, Buddhists rejected traditional Vedic sacrifices and, thus, the memorization and recitation of Vedic works that went along with them. ${ }^{15}$

Although Western scholars sometimes categorize the Vedas as "scriptures," it remains that writing in South Asia seems to have developed primarily apart from Vedic ritual discourse. ${ }^{16}$ Orality and memory continued to be central to intellectual prestige and poetic practice, especially in Sanskrit. The development of writing in South Asia seems to have emerged alongside regional diversity and the development of vernacular languages. Textual-

12 Steve Farmer, Richard Sproat, and Michael Witzel, "The Collapse of the IndusScript Thesis: The Myth of a Literate Harappan Civilization," Electronic Journal of Vedic Studies 11-12 (2004): 19-57.

13 Written in Kharoșțī̄, a script related to Aramaic, Gāndhārī birch bark manuscripts provide important early evidence for Buddhism in the Peshwar and Swat valleys and the region surrounding Taxila; see further Richard Salomon, Ancient Buddhist Scrolls from Gandhära: The British Library Kharoșthī Fragments (Seattle: University of Washington Press, 1999); Andrew Glass, "A Preliminary Study of Kharoșțhī Manuscript Paleography” (MA thesis, University of Washington, 2000); Glass, Four Gāndhārī Samyuktāgama Sūtras (Gandhāran Buddhist Texts 4; Seattle: University of Washington Press, 2007); Jason Neelis, Early Buddhist Transmission and Trade Networks (Leiden: Brill, 2011).

14 So too Salomon, Indian Epigraphy, 8; see further below.

15 Needless to say, the relationship between early Buddhists and Brahmins was nevertheless quite complex; see, e.g., Johannes Bronkhorst, Buddhism in the Shadow of Brabmanism (Leiden: Brill, 2011).

16 William A. Graham, Beyond the Written Word: Oral Aspects of Scripture in the History of Religion (Cambridge: Cambridge University Press, 1993), esp. 70-77, points to the example of the Vedas as valuable for challenging assumptions about orality and scripture within other religious traditions as well. 
ity becomes important in relation to legal proclamations, mythology, and commentary traditions from both Buddhist and Hindu sources. The development of sophisticated manuscript traditions, however, does not wholly displace the emphasis on the ideal of the oral text. ${ }^{17}$

This oral emphasis has a couple of effects on the status of the manuscript and its development. On the one hand, manuscripts are often treated as if a byproduct of recitation, and their materiality is part of the realia of an oral-oriented ritual culture. ${ }^{18}$ Manuscripts are often employed as aides to memorization. Thus, for instance, we see that when Vedic works are eventually written down for the first time after the tenth century, a tradition of highlighters, copyists, and accentors emerged in addition to the traditional role of the Vedic reciter. The standard name for a Vedic reciter is the title of bbatța, which is used widely as an epithet of a scribe. The title evokes the dual role of the priest who writes the text but who is equally capable of reciting it. In Penn's seventeenth-century copy of the Rgveda (fig. 2), originally from the famous library of Kavīndrācārya Sārasvatī, we can glean a lot of information of this sort. ${ }^{19}$

For instance, we see that two brothers, named Kṛ̣na and Gaṇeśa, with the family name Kherde, served as copyists and reciters of the text, while a third person, Nārāyaṇa Bhaț̣a, had the job of accenting the text, a practice known as svarita. This practice of adding red accents, to aid in recitation, is

17 This oral emphasis is not for lack of knowledge or skill in writing or the expertise or patronage of manuscript scribes; as Rao notes: "Why was there . . such a cultivated indifference towards writing and recording systems even after writing became available in antiquity (by the time of Panini)? . . . [E]ven when writing made decisive inroads into Indian cultural practices why is it that vocalic utterance, acoustic elaborations of compositions and embodied performatives contribute to regulate creative and reflective work even to this day? This question gains even more significance when one notices that the Indian scribal output surpasses all the archives of ancient and medieval Europe put together by at least 1,000 times" (Cultures of Memory, 69).

18 Salomon similarly notes "a pervasive, if unspoken, attitude that the written word is essentially a reflection rather than a true manifestation of language," and he suggests that "this may explain the relative lack of attention to the aesthetic aspects of writing in traditional India, as well as the carelessness and imprecision which characterize many, though by no means all, of the written documents, both epigraphic and non-epigraphic, of ancient India" (Indian Epigrapby, 7-8).

19 UPenn MS Coll. 390, Item 81, dated to 1666-1671 CE. 


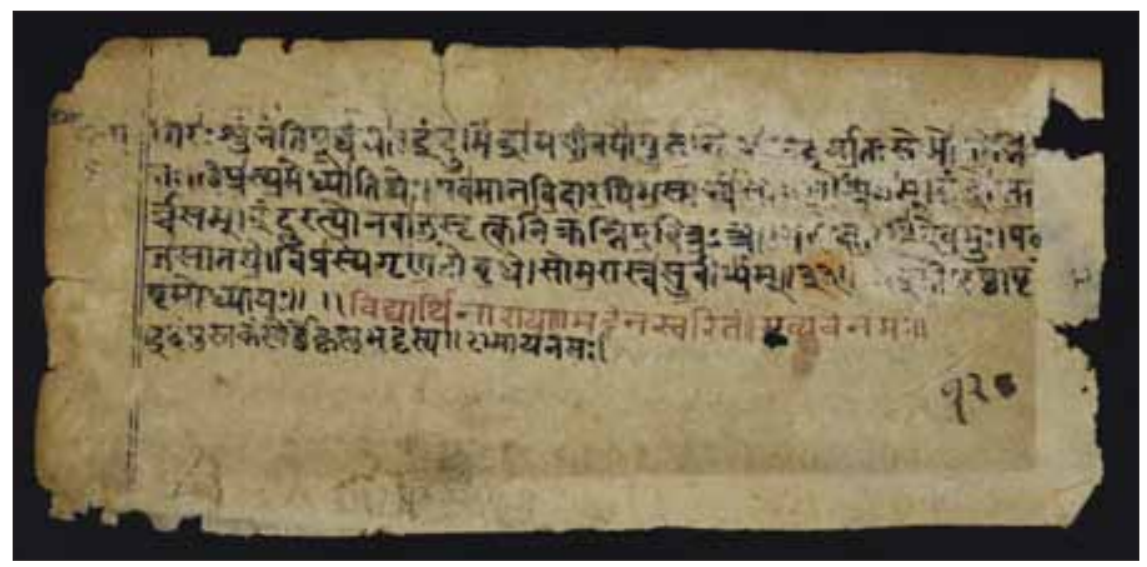

Figure 2. Copy of Rigveda from the library of Kavīndrācārya Sārasvatī. University of Pennsylvania Libraries MS Coll. 390, Item 81; dated 1666-1671. Photo by Benjamin Fleming.

common in manuscripts especially with respect to the Vedas and Upanișads. Thus, this is an important work for giving us insight into details about the scribal practices of Vedic texts and their relationship to the oral narration of sacred literature from late medieval Vārānasī.

In some cases, moreover, the textual variance among manuscripts of a work may reflect a ritual or narrative continuum whereby there is a certain level of fluidity of text. Purānas, for instance, are anthological in character and tend to be unstable rather than fixed in their written forms, and this lack of stability likely reflects their connections and interactions with oral tradition. ${ }^{20}$ Orally-transmitted traditions are routinely allowed to enter into the construction (i.e., writing, redaction, performance) of "texts," subsequently transforming them into newer, modified works. Their forms are also subject to changes as the result of scribal working and redaction, but the processes of literary revision, addition, re-contextualization, and excerption within many Purānas seem to be best understood in conversation with changing settings of recitation and reinterpretation. These dynam-

20 Rocher, “Orality and Textuality," 18-22. 
ics can be seen at the level of the manuscripts: in many cases, the relative "messiness" of a purānic manuscript tradition may not be the result of a lack of care on the part of scribes so much as the product of the open-ended process of textualizing a Purāna. The process of lifting out and reintegrating parts of a tradition, whether oral or written, forms part of the process of their construction and continued use. ${ }^{21}$

The pattern seen within purānic manuscripts forms part of a broader tendency in South Asian manuscripts, which I have found common especially among the Hindu works in the Penn Indic collection-that is, for the forms of manuscripts to reflect a functional idea of writing, where the material text forms part of a broader economy of ritual action and recitation that engages a given work dynamically in religious life. In such instances, the words and structure of a work may remain more fluid, and it may take generations (if ever) for it to be fixed or stabilized in a single form. Functional texts of this sort are sometimes quite fragmentary. Hundreds of Penn's numerous Sanskrit manuscripts, for instance, are no more than a few folios in length. Some are short selections drawn from larger works or fragments of works claiming to be sections of larger works. At times, the idea of a "text as a whole" is rendered into question when considered alongside of its varied physical manifestation as parts and combinations of parts. The forms of such manuscripts, in any case, are designed to be functional within an oral or ritual context, often with less attention to aesthetics. While this is certainly not a unique feature, I might argue that the oral structure behind many South Asian texts-and especially religious works-exemplifies the types of dynamic textual fluidity that cannot simply be accounted for by scribal error but rather express the life of a text in ritual, recitation, and memory.

In the Middle Ages, one also finds another tendency within South Asian manuscript cultures, which approaches the material text not as an aid to the embodiment of a text in speech, memory, and ritual, but rather as an object. This second tendency is found to some extent in Hindu works but is

21 I discuss this phenomenon in more detail in Benjamin J. Fleming, "Mapping Sacred Geography in Medieval India: The Case of the 12 Jyotirlingas," International Journal of Hindu Studies 13 (2009): 51-81; see also below. 
especially prominent within Buddhist and Jain works. The manuscript, in such cases, is an object of beauty - gilded, highly illustrated, illuminated, with fine attention to style of hand. The material form of a work becomes a physical embodiment of religious aura or presence, enhancing the experience of the text as object. Such treatment is typically reserved only for the very well-known works (e.g., Bhagavadgitā, Perfection of Wisdom sutras), and often it is paralleled by efforts to fix and codify its text in a stable form. The manuscript serves as a powerful material object on the level of sight, rather than hearing or memory, with the addition of images and gold leafing emphasizing its physical presence over its content and evoking an experience of the sacred-what is often called the "cult of the book."22

My recent edited volume on Material Culture and Asian Religions includes a number of non-Western test cases for rethinking texts as physical objects. ${ }^{23}$ We argue that text and manuscript can be approached as separate but complementary entities that resist simple conflation, and we suggest an approach to material texts that brings attention to their physicalitywhether inked, painted, carved, or inscribed on metal, stone, wood, skin, cloth, leaves, or wood, or printed on paper, and/or expressed and transmitted orally through the voice, "concretized" in formalized patterns of rhythm, verse, and cadence from mouth to ear. ${ }^{24}$ In my article for that volume, I explored a set of manuscripts held at the Deccan College in Pune as a basis for exploring how the traditional South Asian emphasis on memo-

22 Gregory Schopen, "The Phrase sa prthivīpradeśaś caityabhüto bhavet in the Vajracchedikā: Notes on the Cult of the Book in Mahāyāna" and "On Sending the Monks Back to Their Books: Cult and Conservatism in Early Mahāyāna Buddhism,” in Figments and Fragments of Mabāyāna Buddhism in India: More Collected Papers (Honolulu: University of Hawai'i Press, 2005), 25-62, 108-53; cf. David Drewes, "Revisiting the Phrase sa prithivīpradeśaś caityabbūto bhavet and the Mahāyāna Cult of the Book," Indo-Iranian Journal 50 (2007): 101-43. See further below.

23 Benjamin Fleming and Richard Mann, eds., Material Culture and Asian Religions: Text, Image, Object (London: Routledge, 2014).

24 As simultaneously "text" and "object," amulets and talismans should be included in this continuum as well; e.g., Justin McDaniel, "The Material Turn: An Introduction to Thai Sources for the Study of Buddhist Amulets," in Fleming and Mann, Material Culture and Asian Religions, 135-50. 
rization has had a significant impact on the production of manuscripts. ${ }^{25}$ These manuscripts are dedicated to the worship and praise of the Hindu deity Śiva, and they are primarily list-based, which served as a means to aid in the memorization of the text; the physical manuscript, in fact, was something akin to a glorified Post-it note: it was folded into a very small rectangle, to be carried around on one's person. These manuscripts are anything but works of beauty and were not made to be "seen" in the sense of the visual contemplation of an image of worship, temple architecture, or a painting. The script is rough and full of mistakes and not much attention is given to correcting or beautifying them. The beauty, as it were, resides in the performance of the list. The aim is the recitation and remembrance of a series of names of sacred sites, thereby creating a kind of virtual pilgrimage across the Indian subcontinent, sanctifying its geography to Siva. The knowledge of trans-regional networks is born and spread through the local transmission and recitation of lists, not least due to the dissemination of such manuscripts in private libraries, temples, and homes.

Another article in the same volume, however, emphasized the materiality of South Asian manuscripts with a focus, instead, on the material text as seen object. ${ }^{26}$ Jinah Kim considers a range of epigraphical sources, especially Buddhist illuminated manuscripts, but also Hindu temples, inscriptions in stone, copperplates, and sculptures. Focusing on the Perfection of Wisdom Sütra and texts from Magadha (Bihar and Bengal), she points to the power of writing to bear both sacred and political authority, against the characterization of South Asian text production as primarily memorization. Drawing on ideas of the "cult of the book," she downplays the predominant scholarly emphasis on South Asian orality and memory, and she suggests that architectural, iconographical, and epigraphic evidence have equally visual and material meaning.

25 Benjamin J. Fleming, "Manuscripts and Shifting Geographies: The Dvādaśajyotirlingastotra from the Deccan College as Case Study," in Fleming and Mann, Material Culture and Asian Religions, 59-72.

26 Jinah Kim, "Seeing in between the Space: The Aura of Writing and the Shape of Artistic Productions in Medieval South Asia," in Fleming and Mann, Material Culture and Asian Religions, 39-58. 
How can we reconcile these two perspectives on the materiality of South Asian manuscripts? One possibility is that religion may play a part in determining an approach to a given work. It may be possible to suggest that Hinduism, Buddhism, and Jainism, while sharing many common traits, diverge somewhat (or perhaps self-differentiate) with respect to text production. Just as Hindus, more than Buddhists, tend to emphasize memorization with respect to text production, so they tend to create texts that are highly functional and less aesthetically beautiful than many Buddhist texts. By contrast, many Buddhist works reflect an emphasis on physical presence; the careful attention to script is especially noteworthy. ${ }^{27}$ Jainism seems to fall somewhere in between the two. ${ }^{28}$ For examples of Buddhist and Jain works from Penn, see figures 3 and 4.

One needs to be careful, of course, with such sweeping contrasts, not least because they can reinforce unwarranted divisions between the study of these religions and encourage misleadingly essentialist interpretations of their differences. Elsewhere, I have argued against essentializing the differences between Hinduism and Buddhism, for instance, with respect to relics and the dead. ${ }^{29}$ In the case of differences in the assessments of Kim and myself, our choices of examples in some ways dictated the seeds of both our arguments. In both cases, such seeds yielded characterizations of text pro-

27 Salomon similarly observes that "Buddhism and Jainism . . . exhibit a higher esteem for the written word," noting that "[i]t is thus not a coincidence that the art of calligraphy is more highly developed in Buddhist and Jain manuscript traditions than in Brahmanical circles" (Indian Epigraphy, 8).

28 The University of Pennsylvania Libraries currently have perhaps around twenty Jain and fifty Buddhist manuscripts, and possibly more, as most have yet to be catalogued. For instance, there are a number of beautifully illustrated Jain works from Rajasthan such as MS Coll. 390, Item 3001, a copy of the Pravacanasāroddhārasūtra by Nemicandra (1652 CE), as well as MS Indic 9, a copy of the Sangrahañisūtra, a work on Jain cosmology, by Śrīcandrasūrī. There are also several Buddhist canonical works in Pāli in Burmese script, written on highly lacquered board or paper with gold or silver painted on red. Such works include MS Coll. 390, Item 2978, as well as Item 3000, a Northern Thai gilded palm leaf work, and many others. All of the Penn Libraries' Jain and Buddhist works are housed in one of three collections: MS Indic, MS Coll. 390, and MS Coll. 990. 29 Benjamin J. Fleming, "Relics, Lingas, and Other Auspicious Material Remains in South Asian Religions,” Material Religion 10 (2014): 452-71. 
Fleming: The Materiality of South Asian Manuscripts from the University of

40 | Journal for Manuscript Studies

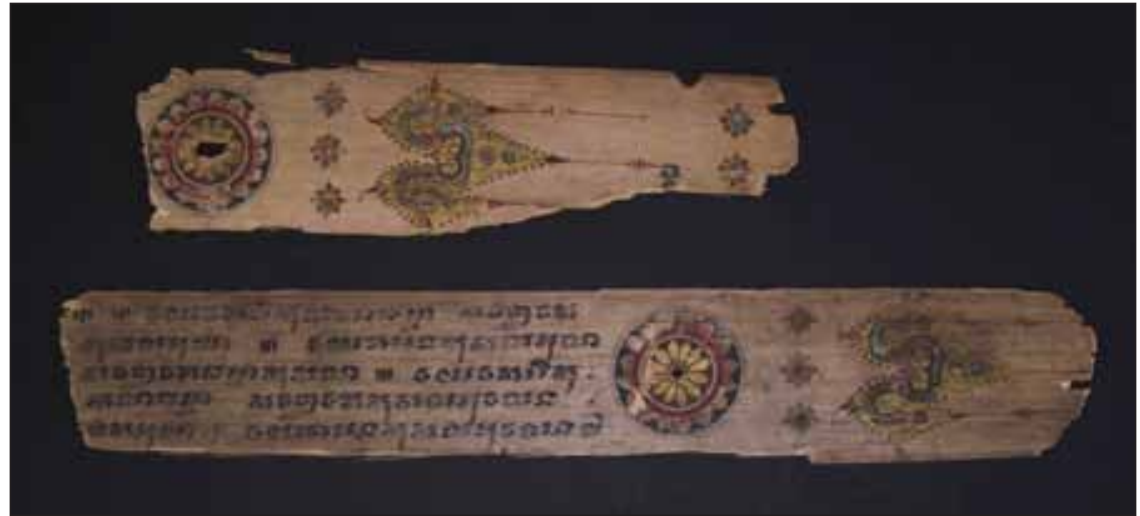

FIGURE 3. Unidentified Buddhist palm-leaf fragment from Southeast Asia. University of Pennsylvania MS Coll. 390, Item 2988. Photo by Benjamin Fleming.

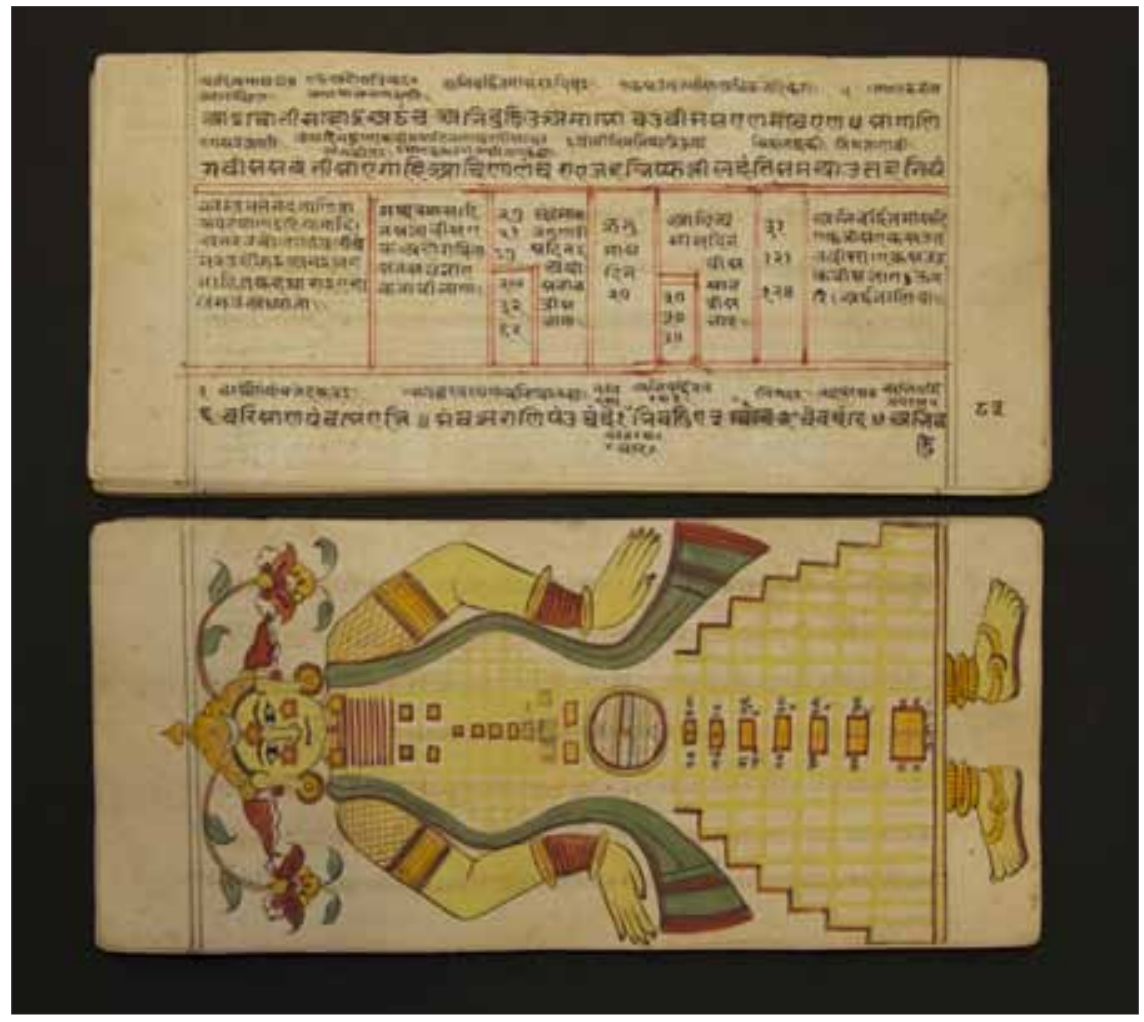

FIgU Re 4. The Pravacanasārodhāra Sūtra by Nemicandra (a Jain work). University of Pennsylvania MS Coll. 390, Item 3001; dated 1652. Photo by Benjamin Fleming. 
duction in South Asia that resonate with other materials too, but neither gives a full picture. It seems appropriate, then, to have the two views sitting uncomfortably side-by-side in the same volume, pointing to a key tension within text production in South Asia.

Across religious traditions and across periods of time, we find both an aesthetic and a functional component to the materiality of manuscripts, and these components are partly determined by the type and genre of work. Accordingly, while I think that one may well hold a general tenet of difference between Buddhist and Hindu scribal practices, there is certainly no shortage of Hindu scriptures that point to a strong emphasis on aesthetics and the look of the text as a visual object. Works in Bengali script are especially beautifully done (fig. 5) as well as many canonical sources and their commentaries in Devanagārīi. ${ }^{30}$

The suggestion of a separation, moreover, distracts from their interconnection; there is ample medieval evidence suggesting connections of ritual, patronage, pilgrimage, etc., between Buddhists, Brahmans, Śaivas, and others in the Indian subcontinent and beyond. ${ }^{31}$ In Bangladesh, one sees similar hints of this even today: the Rāmamālā Library houses primarily Hindu works, for instance, but the family of librarians responsible for its care are Buddhist.

\section{The Rāmamālā Library Project}

The other main dimension of the materiality of South Asian manuscripts concerns their preservation and deterioration: the South Asian climate is particularly harsh on palm leaf and paper. Today, the majority of surviving manuscripts date from the late medieval, Mughal-era, and early modern periods. The quantity is vast. Dominik Wujastyk, for instance, cites Da-

30 See, for instance, MS Coll. 390, Item 765, a Bengali copy of the Tantrasāra by Kṛ̣nānanda Āgamavāgīśa Bhațțācārya, dated to 1663, as well as Item 2248, the Harivamśoddyota.

31 I discuss medieval examples that engage writing and textuality in the sense of inscriptions in "Making Land Sacred: Inscriptional Evidence for Buddhist Kings and Brahmin Priests in Medieval Bengal,” Numen 60 (2013): 559-85. 


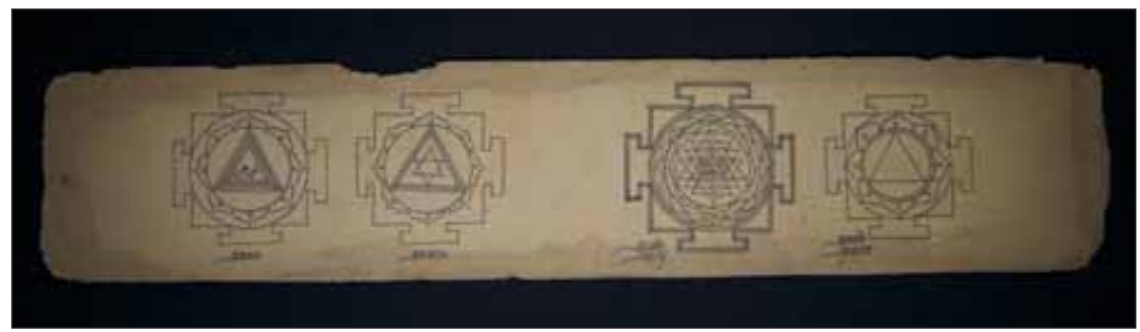

Figu Re 5. Tantrasāra by Kṛ̣nạananda Āgamavāgīśa Bhațțācārya, from the Rāmamālā Library, Comilla, Bangladesh. Dated circa 19th century C.E. Photo by Benjamin Fleming.

vid Pingree's estimate of 30 million South Asian manuscripts across both public and private collections. ${ }^{32}$ Wujastyk further notes that "a back-of-anenvelope calculation based on estimated figures and attrition rates suggests that several hundred Sanskrit manuscripts are being destroyed or becoming illegible every week" simply because of the ravages of time, and "it is inevitable that some of these losses will include unique, unknown, or otherwise important works." ${ }^{33}$ Accordingly he stresses that "the future survival of this Indian literary and intellectual heritage today depends on the discovery, conservation, preservation, and reproduction by digital means of the last generation of Indian manuscripts." 34

The very pressing nature of these types of efforts became clear to me through my work with the Rāmamālā Library in Bangladesh. The Rāmamālā Library is a branch of the Mahesh Charitable Trust that also runs a school, a temple, a hostel, and an Ayurvedic medical center. It is located in the city of Comilla, part of an ancient district called Samatata mentioned in both Hindu and Buddhist copperplate inscriptions dating back to the ninth century. ${ }^{35}$ It is home to an ancient Buddhist university,

32 Wujastyk, "Indian Manuscripts," 160.

33 Wujastyk, "Indian Manuscripts," 160-62.

34 Wujastyk, "Indian Manuscripts," 172.

35 Samatața is especially well known for its inclusion in Candra and Pāla dynasty copperplate inscriptions; Benjamin J. Fleming, "New Copperplate Grant of Śrīcandra (no. 8) from Bangladesh," Bulletin of the School of Oriental and African Studies 73 (2010): 225-26. 
the Salban Bihara, and has a rich history associated with Hinduism since at least the tenth century, when Hinduism made significant inroads in that region and began to slowly, but never totally, displace Buddhism through the spread of Brahmanism. ${ }^{36}$ Buddhism has maintained a small foothold in the region, even into the present day; today, Buddhists make up about 1 percent of the total population, although many of these are immigrants from Myanmar (formerly Burma) who left that country during its period of civil war and in 1948. Hinduism, by contrast, has maintained a larger presence in the region with close to 10 percent of the total population of Bangladesh naming Hinduism when asked to identify their religion, although most of the outside world identifies Bangladesh as a Muslim nation with close to 90 percent of the population identifying to varying degrees with that religion (i.e., with many secular or casual Muslims and only a small albeit powerful group that might be deemed "fundamentalist").

Despite the current demographics, much of the religious history of this region is related to Buddhism and Hinduism with the introduction of Islamic civilizations and cultures integrating with the latter after the twelfth century. Much of the culture centers around shared food and language rather than differences in religion, however, and perhaps more than anything else, it has been the incursions and subsequent politico-religious manipulation and forced partition of Muslims and Hindus by the British, with the formation of Pakistan and East Pakistan in 1947, that has wrought the identification of Bangladesh as a Muslim nation. By bifurcating Bangladesh from West Bengal, the longstanding cultural continuity was replaced by a somewhat artificial division on religious rather than historical or political grounds. The travesty of that separation is perhaps best seen with the violent formation of Bangladesh in 1971, when the country broke away from Pakistan to strike out on its own, albeit now crippled, to an extent, by its cultural disconnect from West Bengal.

The manuscript collection of the Rāmamālā Library was established prior to these divisions. Founded in 1935 by Maheśacandra Bhaț̣āaārya, it

36 Bronkhorst, Buddhism in the Shadow of Brabmanism; Fleming, "Making Land Sacred." 
was meant to promote education and preserve Bengali culture. It was also intended as a resource for preserving and promoting Hinduism within a dominant Muslim environment on the eve of British colonialism. It spans approximately nine thousand palm leaf and paper manuscripts, mostly from the latter part of the Mughal and the British eras (roughly 1650-1900 CE). Much of the library is thus dedicated to Sanskrit scientific and legal literature. Yet it also contains unique texts in a variety of other Sanskrit genres, and it preserves many regional works in Bengali, including some rare recensions of the Mahäbhärata (e.g., RLMS 7169, 7311, 7340, 7370) and Rāmāyaña (e.g., RLMS 545, 547, 552, 569). Consequently, it preserves a snapshot of the literary and religious culture of the region in pre-colonial and colonial times.

The collection has been physically displaced twice-first, during the upheavals in 1947 when India and Pakistan were partitioned, and then again in 1971 when Bangladesh broke away from Pakistan. Initially, Bhaț̣āaārya planned a multi-volume catalogue of the collection. As a result of these upheavals, however, only one volume was completed. It is no longer available, even at the Rāmamālā Library itself. Early attempts to itemize, catalogue, and identify manuscripts have been largely lost. The manuscripts themselves, moreover, suffer from physical neglect and dilapidation. They are housed in rooms with glassless windows and leaky roofs, exposed to the elements, and open to vermin (rats and flying insects) and potential theft (see fig. 6). The current librarian who looks after the collection, Indra Kumar Sinha, is in his eighties and in poor health. Although efforts have been made to try to have his daughter Vavali Sinha replace him as the keeper of the manuscripts, it is feared that when he passes on he may not be replaced and that the collection would become unavailable to the public and even more open to theft. It is thus very pressing to take steps to help preserve this valuable collection and to disseminate knowledge about its contents, so as to be in a better position to protect and preserve it. ${ }^{37}$

37 For example, a comprehensive inventory will be valuable for tracking the manuscripts in the future. 


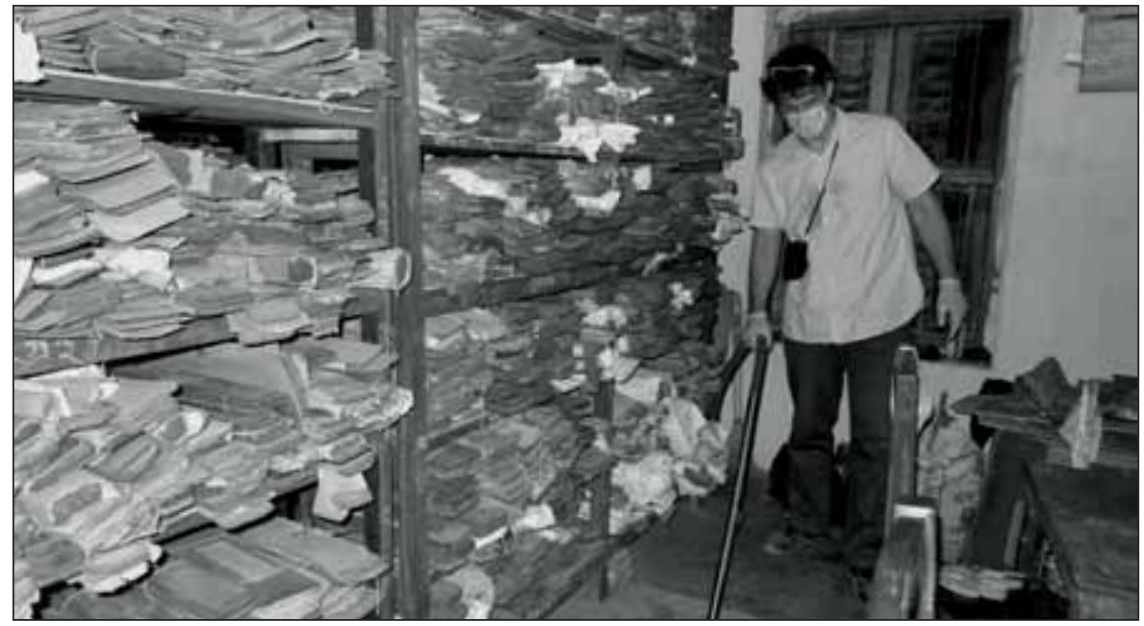

FIgURE 6. The author vacuuming room in Rāmamālā Library; Comilla, Bangladesh, March 2014. Photo by Himadri Debnath.

Since Bangladeshi independence, there had been only limited efforts to ameliorate the disarray of the manuscripts. In the 1980s, through a project funded by the Ford Foundation, scholars from Dhaka University led by Abdul Momin Chowdhury along with Kalpana Bhowmikh identified manuscripts related mainly to Tantra (i.e., esoteric, ritual literature), moved them to their current location in a different room, photographed, and $\mathrm{mi}^{-}$ crofilmed them. The microfilm was held at the University of Dhaka but has completely deteriorated since the Ford Foundation funding ended. ${ }^{38}$ Now, all that remains of these efforts are about six or seven handwritten notes and catalogs. These records cover perhaps only 10 percent of the collection (about one thousand entries). ${ }^{39}$ In the early 1990s, a Sanskrit specialist from

38 The manuscript room at Dhaka University is climate controlled, however, and in general, that institution takes very good care of its holdings.

39 Some entries are repeated making it difficult to assess the exact number; and the catalogs were focused on thematic categories rather than strict numbers. These catalogs exist in the secondary book library apart from the two main manuscript rooms. When we attempted to access copies that were supposed to be at Dhaka University library, they could not be located. There are materials from the Rāmamālā Library included among the 2,143 manuscripts from multiple public and private collections that are listed in the 
Calcutta, Satyanarayana Chakravarti, made preliminary attempts to classify all the manuscripts into general categories; in addition to the Tantric material, these include poetry, Hindu law, astrology, medical literature, Sanskrit grammars, dictionaries and word glossaries, ritual literature, ritual epistemologies, commentaries, mythology, and devotional and liturgical literature. From 2009-2012, Thibaut d'Hubert and Saymon Zakariya identified three hundred works of poetry (kāvya) and gathered their titles, contents, and physical descriptions as well as photographing a handful of the manuscripts using a low-resolution camera; their work confirmed the significance of the collection and sparked a joint project to produce an edition of a poetic commentary by Rūpa Gosvāmin, a sixteenth-century Hindu saint. Despite the promise of these preliminary efforts, the full scope of the collection had remained unknown, and little had been done to address the poor state of preservation of the manuscripts.

With funding from the British Library Endangered Archive Programme, I traveled to Bangladesh in early 2014 with the aim of creating a complete inventory of the collection, training local scholars to digitize and preserve the manuscripts, and digitizing a sample of selected rare and at-risk works. During four months in Bangladesh, I was able to gather and train a team of local scholars. We succeeded in cataloguing almost all of the collection-even after discovering that its size was not six thousand manuscripts, as had been initially estimated, but rather nine thousand! During the process of cataloguing it became clear that the collection is important for its unique texts that highlight the interchange of Bengali and other regional dialects with Sanskrit. The library also houses some hybrid works and unique regional narratives, as well as mythological, medical, philosophical, grammatical, and other works. These encompass not just Hindu works, but also works related to a distinctive, regional, guru-centered vari-

printed alphabetical index of manuscripts catalogued and microfilmed in the 1980s by Chowdhury and his team with Ford Foundation funding; An Alphabetical Index of Sanskrit, Bengali, and Persian Manuscripts (Microfilms), Prepared by the Ford Foundation Project (Dhaka: Dhaka University Library, 1995). This alphabetical index, however, does not specify the library or collection in which any of the listed manuscripts are located. 
ety of Islam called Satyapir,${ }^{40}$ which is a movement closely aligned with the Satyanārāyaṇa, a Hindu movement centered on the deity Nārāyaṇa (a form of the god Viṣnu). ${ }^{41}$ We even discovered one codex in Arabic (RLMS 4928). In addition to the collection's unique contents, the manuscripts offer important evidence for regional scribal practices, marginalia, and traditional preservation techniques, which are not otherwise well known.

The aim of the foundational inventory was to serve as the basis for assessing its value and setting up more extensive conservation and digitization projects. During the inventory, we physically assessed the state of the collection and began to outline a workable strategy for its continued maintenance and preservation that would extend beyond the current project and towards possible future collaborative projects at a larger scale. Preservation efforts included the rehousing of many of the worst-case manuscripts, stripping away acidic newspapers from the 1940s and then rewrapping them in cotton cloth (referred to locally as "marking cloth" or "marking kāpaḍ"). I also trained local scholars on the basic techniques of digitization of manuscripts using high-quality camera equipment as well as how to process the data using Adobe Lightroom, Bridge, and other professional software. In addition, we held a two-day workshop about cataloging and creating an inventory with students and scholars from Comilla. These initiatives were to help establish a sustainable knowledge base for local scholars, who could also continue to digitize and preserve these and other manuscript collections even beyond this particular project.

In addition, we were able to digitize eighty-four manuscripts. I am currently working to make these materials accessible to the global public through Penn's user interface Penn in Hand with a Creative Commons license, which will be attached to all digital images and their metadata. ${ }^{42}$ This set of manuscript images highlights some of the unique texts from the Samatata region

40 There are, for instance, numerous works under the title Satyapīrer Pāñcāli, e.g., RLMS 7255, 7294, 7295, and 7300.

41 See, for instance, the various works bearing the title Satyanārāyaṇa Pāñāalì, e.g., RLMS 738, 6655, 6656, 8138, 8374, and more.

42 Attribution-NonCommercial-ShareAlike 3.0 Unported http://creativecommons.org/ licenses/by-nc-sa/3.0/). Copyright will remain with the Rāmamālā Library, although the British and University of Pennsylvania Libraries will be free to share, copy, distribute, transmit, and adapt the work; commercial use of the images will not be allowed. 
of Bangladesh, an ancient district possessing a diverse religious and cultural heritage. It will be useful to scholars in North America and Europe but also in India, Bangladesh, and elsewhere in Asia; in particular and very importantly, the low-bandwidth requirement for Penn in Hand will enable scholars even in third-world countries to have access to these manuscripts.

\section{Conclusion}

Examples from South Asia make clear the importance of giving attention to the materiality of manuscripts. In some cases, as noted above, the manuscript may be a secondary or supplementary product within a broader culture of oral recitation and ritual performance, which together create a synchronic, layered text embedding cultural and historical information into the fabric of a given work. In other cases, the content of the manuscript may be codified or assumed, while its physical features are emphasized and brought to the foreground to vivify or convey the meaning of the text. Such subtleties and differences get lost when "texts" are approached as wholly fixed or stable entities, abstracted from the material forms and social contexts of their use and transmission.

Due to the vast quantity of South Asian manuscripts, and the local and other variations of traditions preserved within them, much is lost when one accesses a work only through printed editions, and much can be learned from looking to their materiality. In trying to wrestle with the discrepancy between Kim's and my own piece, and why we might both come up with very different approaches to South Asian text production, for instance, I have found the experience of cataloguing manuscripts especially valuable. An art historian will approach a manuscript quite differently than a cataloguer, and it is perhaps not surprising that such different approaches would yield different results. Among the value of cataloguing is the capacity of considering mass numbers of materials. Throughout my doctoral and postdoctoral research, and especially with my work with the collections at Penn and in the Rāmamālā Library in Bangladesh, I have examined more than ten thousand manuscripts—including thousands of Hindu manuscripts, hundreds of Buddhist manuscripts, and dozens of Jain manuscripts. Some 
broader patterns emerge: I have found that many technical manuals, prayer manuscripts, and other works related to rites and ceremonies put significantly less value on the finished product of the material text. Manuals to be employed in rites, ceremonies, and rituals tend to be hastily written, and poorly conceived as objects. Among the thousands of manuscripts held in the Rāmamālā Library, I found that special attention had been given to standardized works such as grammars. The most notable among these is the Daurgasimbavrtti by Durgasimha, a regional Sanskrit grammar and commentary. Such large works, in addition to being finely scribed in a fluid Bengali style, are encased in wooden boards, and the frayed edges have been cleaned with what appears to be iron-gall ink (which burns the paper) or possibly by fire itself, thus creating a kind of burnt "gilded" effect that helps to protect the works from insects. The patterns in Penn's Indic collection generally fit the contrast noted above, with the more developed, illustrated works more typically seen in Jain and Buddhist manuscripts on the whole rather than Hindu manuscripts. ${ }^{43}$ The collection includes some Hindu exceptions to this general pattern. Interestingly, however, most of Penn's illuminated Hindu manuscripts are also atypical in that they are codices, raising the possibility that their highly worked material forms might reflect concerns that came into Hindu text production rather late. ${ }^{44}$

South Asian examples such as these make especially clear what is lost in a printed edition or e-texts of a work-that is, a sense of the fluid nature of the lived text, especially as reflected in the variance of manuscripts as it stands in continuum with oral tradition and ritual use. The printing of a work does much to preserve and disseminate a work, but it can also have the unintended result of giving one version of a "book" the aura of a fixed, static, or unchanging abstraction, fractured off from its lives as a physical

43 This pattern echoes, to some extent, what Losty has suggested more broadly, that "the Hindus [as compared to Buddhist and Jain tradition] had missed one thousand years of calligraphic development, and their task was one of urgently recording literature that might disappear for ever rather than of writing texts as beautifully as possible." See Jeremiah P. Losty, The Art of the Book in India (London: The British Library Board, 1982).

44 See, e.g., MS Coll. 390, Items 2639 and 3009, as well as MS Indic 5. 
object. This is certainly the case in the age of the Internet, with the dissemination of e-texts, and explains why the development of manuscript digitization projects is now so vital. Grappling with manuscripts allows us to maintain a feel for the work's existence as a sequence and lineage of situated and specific material objects, and this effort is perhaps especially pressing for South Asian and other contexts in which such material texts were often so closely linked to orality.

Is a text something that we can ever think of without material properties? Certainly this seems to be the case, more and more, in the digital age. In the case of e-texts, the loss of the tactility of words gives many of us pause and, indeed, impels much of our work on manuscripts - that is, to bridge the gap between what is both lost and gained through digital media. Even a decade ago, the prospect of large-scale digitization of manuscripts was unimaginable, due to the bandwidth needed to handle large raw or TIFF files. But it is now a vibrant reality at Penn and other research libraries. The physical forms of many types of Asian manuscripts, especially those from Bangladesh and Southeast Asia, pose some practical challenges to a system of digitization designed with the codex and Western-style book in mind. Their prominent form-thin and long like a palm leaf-makes them difficult to photograph in a manner that conforms to what is considered the minimum "standard" resolution of $300 \mathrm{dpi}$. In addition, in practice, attempts to digitize manuscripts in collections in South Asia, such as the Rāmamālā Library, can run up against misunderstandings of what digitization and Creative Commons even entail. This is often exacerbated by the long history of colonial domination, and one may encounter an embedded suspicion towards projects with foreign funding. Equally, the idea that Western cultures are still trying to pilfer Asian collections remains widespread.

Nevertheless, the prospects are especially promising. In the past, manuscript libraries could be catalogued only by making records of titles and through photographic records on microfilm; the latter was thought to revolutionize the preservation of manuscripts. In South Asia, however, microfilm has been subject to the same climate and other conditions that put manuscripts in such danger of deterioration and losses (e.g., humidity, cold, fire, water damage, etc.). This is exactly what happened with the Ford 
Manuscript Studies, Vol. 1 [2017], Iss. 1, Art. 3

Foundation funded project through Dhaka University, mentioned above. What is now possible, with more advanced technologies, is that multiple institutions can host virtual copies of collections without having to move the physical collections. In Penn's case, we have some Buddhist palm leaf manuscripts from the University of Arizona, and we will soon host the digital files of eighty-four works from the Rāmamālā collection. Not only is the technology for preservation much better than that of the 1980s, but the digital files can be held in multiple locations simultaneously and made available for free download - thus ensuring their survival, even outside the bounds of the traditional library. 